\title{
ETNOSENTRISME DAN SIKAP INTOLERAN PENDATANG TERHADAP ORANG PAPUA
}

\author{
Elia Nurindah Sari $\left({ }^{1 *}\right)$, Samsuri $\left(^{2}\right)$ \\ ${ }^{12}$ Department of Civic Education, Graduate School of Universitas Negeri Yogyakarta, Indonesia.
}

\begin{tabular}{ll} 
ARTICLE INFORMATION \\
\hline Submitted & $: 28^{\text {th }}$ September, 2019 \\
Review & $: 03^{\text {rd }}$ April, 2020 \\
Accepted & $: 22^{\text {nd }}$ May, 2020 \\
Published & $: 1^{\text {st }}$ June 2020 \\
Available Online & $:$ June, 2020 \\
& \\
KEYWORDS
\end{tabular}

Ethnocentrism; Intolerance; Tolerance; Papua

\section{CORRESPONDENCE}

*E-mail: elianurindahsari@gmail.com

\begin{tabular}{l} 
A B S T R A C T \\
\hline This article is aimed to raising awareness for pluralistic Indonesian. \\
Awareness to be able to appreciate anything about the differences in \\
Indonesia, including those who are from Papua. Indonesia is now has \\
any issues of tolerance. Although there are many public slogans or \\
appelas to be tolerant, in fact not a few cases of intolerant attitudes \\
occur. There are so many cases that lead to racism in Papuans. \\
Ethnocentrism attitude told us how someone from a certain group feels \\
better than another group. This will be linked to the intolerant attitudes \\
to the Indonesian people towards Papuans, and learning study \\
implications of what happened from that situation. The purpose of this \\
article is to build awareness of all Indonesians to reduce their intolerant \\
attitude towards Papuans. This article used the method of literature \\
review. Some of the literature taken is, among others, related to the \\
literacy of tolerance, Papuans culture and some cases of Indonesian \\
intolernace towards Papuans. The results of research through this \\
literature study found that intolerant cases carried out by non-Papuans \\
against Papuans had implications or the attitude of Papuans who \\
became inferior, lacked confident and felt unappreciated.
\end{tabular}

\section{A. PENDAhUluan}

ndonesia adalah negara majemuk, hal ini merupakan suatu wawasan nusantara yang dipahami seluruh warga negara Indonesia. Bhineka Tunggal Ika, semboyan bagi bangsa Indonesia untuk memahami bahwa negara majemuk ini memiliki banyak jenis budaya, bahasa, ras, suku, agama dan lain sebagainya. Kemajemukan ini melahirkan suatu kewajiban bagi Bangsa Indonesia agar dapat bersikap toleran terhadap berbagai macam perbedaan yang ditemui di Indonesia. Namun sayangnya, akhir-akhir ini terjadi banyak sekali peristiwaperistiwa intoleran di dalam bangsa ini. Kasuskasus yang paling sering terjadi adalah kasus intoleransi mengenai agama dan ras.

Kasus intoleran yang masih hangat dalam ingatan adalah mengenai kasus mahasiswa Papua yang kuliah di Pulau Jawa, tepatnya di Surabaya. Kasus ini bermula ketika ditemukan bendera merah putih yang rusak di depan asrama mahasiswa Papua tersebut. Hal itu menimbulkan reaksi dari aparat dan ormas yang mengepung asrama tersebut. Pihak aparat menduga perusakan bendera merah putih dilakukan oleh oknum mahasiswa Papua yang tinggal di asrama.

Beberapa hal yang disayangkan dari tindakan di atas adalah pada saat aparat dan ormas menyerang asrama mahasiswa Papua, mereka tidak terlebih dahulu melakukan investigasi mendalam sebelum melakukan pengepungan ke asrama. Selain itu, aparat juga malah membiarkan ormas yang reaksioner turut melakukan pengepungan. Aparat juga mengucapkan katakata yang bernada rasisme terhadap mahasiswa Papua. Hal ini menunjukkan bahwa kita sebagai rakyat Indonesia non Papua, belum bisa menghormati satu sama lain dalam hidup berbangsa.

Terlepas dari hal apa yang melatarbelakangi masalah tersebut, memiliki sikap toleran selalu masuk menjadi kunci pencegahan dari kasus- 
kasus rasisme. Maka dari itu menjadi penting ketika sebagai warga negara yang majemuk kita memahami dulu bahwa Negara Indonesia ini negara yang luas dengan segala macam perbedaan di dalamnya. Mempelajari sikap toleran dari sisi kasus-kasus intoleransi dan berbicara mengenai etnosentrisme diharapkan dapat membuka mata bangsa ini bahwa kita pada intinya harus mengakui bahwa kita berbeda dan kemudian dapat menerima perbedaan tersebut dengan sikap yang bijak.

Berangkat dari jurnal fenomenologi pengalaman penyesuaian diri mahasiswa Papua di Surabaya (Wijarnako \& Syapiq: 2013), menyatakan bahwa mahasiswa Papua di Surabaya mengalami berbagai hambatan dalam menyesuaikan diri. Penyebab hambatan tersebut adalah perbedaan dalam bahasa dan kebiasaan budaya. Hal lainnya yang menyebabkan adanya hambatan interaksi dengan warga lokal adalah karena perbedaan warna kulit dan perbedaan fisik.

Perbedaan bahasa menjadi penyebab interaksi. Dikarenakan mahasiswa Papua tidak memahami bahasa lokal, dalam hal ini bahasa Jawa, mereka kerap kali salah faham terhadap warga lokal saat sedang berbicara dengan bahasa Jawa sambil tertawa. Mereka merasa tersinggung karena merasa sedang menjadi bahan perbincangan.

Perbedaan fisik yang dimiliki orang Papua juga dirasakan membuat mereka sering dipandang seperti orang asing. Mereka kerap kali dipandang secara berbeda dan ditertawakan oleh warga lokal (Wijarnako \& Syapiq: 2013). Hal senada juga terjadi pada mahasiswa Papua di Kota Malang. Tindakan warga lokal terhadap mahasiswa asal Papua yakni sering melihat dengan pandangan aneh dan menertawakan (Ulaan, dkk: 2016). Hal semacam ini membuat mereka merasa minder, kurang percaya diri dan merasa berbeda dengan warga lokal. Mahasiswa Papua membutuhkan pengertian untuk dipahami oleh warga lokal atas perbedaan yang dimiliki oleh mahasiswa Papua. Hal-hal di atas adalah penyebab seringnya mahasiswa Papua yang melanjutkan pendidikan di Pulau Jawa, cenderung memilih untuk bergabung dengan sesama warga Papua dan terkesan menutup diri dari warga sekitar. Mereka merasa kurang dihargai.

Hal yang paling mencolok dari perbedaan antara masyarakat Indonesia non Papua dengan orang Papua adalah warna kulit. Tidak bisa dipungkiri bahwa kerap kali saat berpapasan dengan orang Papua di tempat-tempat umum, akan mengundang keinginan untuk memandang mereka dengan pandangan lain daripada masyarakat Indonesia non Papua. Maka dari itu penulisan artikel ini bertujuan untuk menjabarkan bagaimana etnosentrisme masyarakat Indonesia non Papua terhadap sikap intoleran yang kerap kali dilakukan terhadap orang Papua.

\section{B. METODE PENELITIAN}

Penulisan artikel ini dilakukan dengan menggunakan metode kajian pustaka. Metode kajian pustaka merupakan metode pengumpulan data melalui telaah terhadap sumber-sumber kepustakaan (Mahmud, 2011). Metode kajian pustaka yang dilakukan yakni dengan memanfaatkan sumber dan bahan kepustakaan yang ada baik dari buku atau artikel, maupun laporan hasil penelitian dari penelitian terdahulu terkait masalah etnosentrisme dan sikap-sikap intoleran terhadap orang Papua. Setelah mendapat beberapa referensi terkait tema penelitian, bahan dibaca bagian poin-poin penting yang berhubungan dengan tema, lalu mengutip informasi, menganalisis kemudian merangkum. Rangkuman selesai, kemudian tulisan digeneralisasikan dengan kajian teori yang relevan sehingga membentuk satu tulisan hasil penelitian yang utuh.

\section{HASIL DAN PEMBAHASAN 1. Etnosentrisme dan Intoleransi}

$\mathrm{E}$ tnosentrisme merupakan kecendrungan untuk berfikir bahwa budaya etniknya lebih unggul diandingkan dengan budaya etnik lain (Irianto: 2013). Segala sudut sesuatu dilihat dari sudut pandang etniknya sendiri. Etnosentrisme meyakini superioritas kelompok etnis dan kelompok kebudayaannya serta menganggap hina kelompok lain (Myers, 2012). Terdapat beberapa aspek yang menyebabkan timbulnya entosentrisme, yaitu antara lain perbedaan fisik (biologis), perbedaan lingkungan (geografis), perbedaan kekayaan (status sosial), perbedaan kepercayaan, dan perbedaan norma sosial (Ahmadi, 2007).

Etnosentrisme berpeluang untuk menghambat keserasian interaksi dan komunikasi antar etnik (Susanto, 2009). Etnosentrisme adalah fanatisme suku bangsa, yaitu suatu persepsi yang dimiliki oleh setiap individu yang mengganggap bahwa kebudayaan yang mereka miliki lebih baik dari kebudayaan lainnya. Etnosentrisme juga menganggap cara hidup bangsanya merupakan cara hidup yang paling baik.

Kemajemukkan bangsa Indonesia melahirkan banyak sekali wacana yang perlu dipelajari dan ditanamkan sejak dini, seperti salah satunya mengenai integrasi nasional. Banyak hal yang sebenarnya dapat dikaitkan dengan integrasi nasional seperti di dalamnya tentang penghormatan terhadap hak asasi manusia (HAM). Banyak hal yang dapat dijabarkan untuk merujuk pada hal-hal yang berkaitan dengan HAM. 
Toleransi merupakan elemen penting dalam menghormati hak-hak individu yang hidup dalam keberagaman. Sebaliknya juga hak-hak individu dalam keberagaman itu tidak bisa dihormati, maka telah terjadi sikap intoleran.

Sebuah artikel yang ditulis oleh orang Papua, yang menyatakan kekecewaannya atas stigma yang kerap kali muncul dari masyarakat non Papua terhadap orang Papua. Artikel tersebut dimuat dalam sebuah jurnal Indoprogress.com dalam kolom Papua Bicara pada tanggal 22 September 2016. Stigma yang kerap kali muncul dari masyarkat non Papua dalam menyikapi kasus rasisme orang Papua adalah mereka pantas mendapat kecaman dari masyarakat non Papua karena perilaku orang Papua itu sendiri. Orang Papua tidak memiliki privilese seperti masyarakat Indonesia lain yang non-Papua, yaitu ketika ada satu warga yang bersalah maka yang lain tidak akan kena imbasnya. Berbeda dengan orang Papua, ketika salah satu atau sekelompok orang Papua bersalah atas tindakan tertentu, maka seluruh orang Papua mendapat kecaman tersebut. Mereka dikatakan separatis dan sering membuat onar, maka dianggap pantas mendapat perlakuan lain dari masyarakat non Papua.

Papua adalah provinsi terluar di Indonesia. Banyak hal yang dikontribusikan provinsi Papua terhadap bangsa Indonesia melalui sumber daya alamnya. Akan tetapi hal yang saat ini miris terjadi bahwa banyak sekali sikap-sikap intoleran yang ditunjukkan oleh suku-suku lain bangsa Indonesia terhadap orang Papua. Kasus yang masih segar di ingatan adalah kasus penghinaan terhadap mahasiswa Papua dengan kata-kata yang kurang baik yang terjadi di wilayah Jawa Timur. Bhineka Tunggal Ika, berbeda-beda tetapi tetap satu jua. Semboyan untuk bangsa Indonesia yang sudah kita fahami saat di bangku sekolah, namun apakah hal ini lantas dipahami dengan seksama dan kemudian diamalkan dalam kehidupan di masyarakat? Perbedaan suku, ras, bahasa, etnis, agama dan lain sebagainya adalah anugerah bagi bangsa Indonesia. Namun untuk mengelola hal itu semua tidak mudah, perlu suatu formula yang nyata agar bangsa Indonesia mampu memahami itu hingga kemudian dapat hidup berdampingan dengan baik satu sama lain.

Kasus-kasus intoleran yang terjadi di Indonesia, misal dari kasus intoleransi agama. Setara Institue, sebuah lembaga swadaya masyarakat Indonesia yang melakukan penelitian dan advokasi tentang demokrasi, kebebasan politik dan HAM melakukan riset pada tahun 2017 tentang kasus intoleransi agama. Seperti yang dikutip oleh tempo.co pada artikelnya yang berjudul Setara Institue : Intoleransi terhadap Keyakinan Meningkat, menyebutkan bahwa pada tahun 2017 terjadi 80 pelanggaran kebebasan beragama dan berkeyakinan dengan 99 tindakan. Setara menyebutkan peningkatan tersebut secara umum disebabkan beberapa faktor, diantaranya peningkatan intensitas politisasi agama, kasus intoleran yang dilakukan oleh individu dan kelompok keluarga, dan kompleksitas pasal penodaan agama. Dari pernyataan di atas bisa dilihat dua dari tiga faktornya adalah datang dari sikap-sikap individu itu sendiri. Ini memperlihatkan bagaimana lemahnya sikap toleransi bangsa Indonesia tentang beragama. Padahal sudah jelas dalam undang-undang mengenai HAM dijelaskan adanya kebebasan untuk memeluk agama sesuai dengan kepercayaan masing-masing.

Kemudian kasus intoleran terhadap etnis yakni kasus Konflik Sampit pada 2001 silam. Kasus antara etnis Dayak dan etnis Madura yang dilatarbalakangi oleh hal-hal yang sepele. Pertikaian yang sering terjadi dipicu oleh kedua belah kubu memiliki etnosentrisme yang tinggi. Hal tersebut diperparah dengan kebiasaan dan nilai-nilai yang berbeda bahkan berbenturan. Orang Madura biasa membawa parang kemanapun mereka pergi, akan tetapi hal itu malah dinilai lain oleh orang Dayak. Bagi orang Dayak membawa parang dilihat sebagai orang yang siap mengajak bertarung. Maka dari itu jika terjadi masalah sepele pun dapat berakibat besar.

Kasus rasisme lain yang selalu lekat dalam ingatan adalah mengenai kasus rasialisme etnis Tionghoa. Kebencian rasialis dan penindasan terhadap etnis minoritas Tionghoa masih terasa memprihatinkan jika mengingat tragedi kerusuhan 1998. Penyebab dari peristiwa ini adalah salah satunya mengenai rasa iri yang timbul karena perbedaan keadaan ekonomi warga pribumi dengan etnis keturunan Tionghoa. Hal-hal yang semuanya bermula dari individu bisa meledak menjadi masalah bersama, dari situlah kerusuhan dapat mencuat.

Kasus tersebut juga berimbas pada diskriminasi dan konflik kekerasan yang berbau etnis Tionghoa di Surakarta, Jawa Tengah. Etnis Tionghoa yang tinggal di Surakarta sudah bermukim ratusan tahun dan hidup berdampingan dengan warga lokal yaitu masyarakat Jawa. Berbagai sentimen dan konflik etnisitas muncul. Namun upaya rekonsiliasi dan integrasi terus menerus dilakukan demi menjaga kedamaian hubungan yang telah terbentuk antara etnis Tionghoa dan masyarakat Jawa di Surakarta (Purbasari: 2019). Keberadaan etnis Tionghoa di Surakarta memberikan kontribusi dalam memperkaya keanekaragaman masyarakat yang menjadi bukti bahwa adanya multikultural di sana.

Melalui kasus-kasus tindakan intoleransi di atas, satu hal yang menurut penulis dapat ditarik 
kesimpulannya adalah bagaimana sebelum pertikaian antar golongan terjadi, sebenarnya hal itu bermula dari masalah yang terjadi antar individu. Sikap toleransi sangat menjadi hal utama untuk membendung hal yang demikian itu. Beberapa gambaran di atas cukup membuat kita menyadari bahwa betapa Negara Indonesia yang penduduknya majemuk ini masih kurang toleransi.

\section{Tindakan Intoleran terhadap Orang Papua}

Definisi orang asli Papua secara historis muncul dari pengalaman 'memory passionist' akan masa-masa di waktu lalu yang penuh tantangan dan pergulatan untuk menunjukkan jati diri, sehingga dasar ini menjadi konsensus bersama seluruh pemangku kepentingan di Tanah Papua (Deda \& Mofu, 2014). Wikipedia menuliskan bahwa respon penduduk terhadap nama Papua cukup baik. Nama Papua mencerminkan identitas diri mereka sebagai manusia hitam, keriting, yang sangat berbeda dengan penduduk bangsa Indonesia. akan tetapi hal tersebut sangat bertolak belakang dengan respon-respon orang-orang non Papua. Orang Papua tak terima dengan ejekan yang selalu dilontarkan warga pendatang. Ada yang memaknai nama Papua sebagai bentuk ejeken tehadap warga setempat yang primitif tertinggal dan bodoh yang merupakan slogan yang tidak mempunyai arti apapun.

Etnosentrisme merupakan perasaan yang muncul pada suatu bangsa yang memandang cara hidup bangsanya lebih baik dari bangsa lain. Etnosentrisme erat kaitannya dengan sikap rasis. Sejaah panjang rasis salah satunya pada sejarah perbudakan yang pernah terjadi di Amerika Serikat. Para budak adalah manusia-manusia yang dimiliki oleh seorang tuan atas dasar superioritas. Para budak melakukan apapun yang tuannya inginkan,mereka bekerja tanpa digaji dan tidak memiliki hak asasi manusia. Sangat menyedihkan. Dalam situasi ini harga atau nilai kemanusiaannya tidak diperhitungkan lagi atau sudah dicabut. Sistem perbudakan yang demikian tidak hanya terjadi pada urusan perorangan dan dalam urusan pekerjaan rumah tangga, melainkan pada urusan keagamaan sekalipun. Bangunan-bangunan tua megah baik gererja-gereja di daratan Eropa dibangun oleh para budak. Mereka dijadikan alat mekanik untuk mendirikan bangunan megah tersebut.

Praktek perdagangan budak bahkan lazim terjadi pada masa dulu. Dahulu banyak orang Afrika yang diangkut ke Eropa untuk djadkan budak. Mereka dijadkan pekerja kasar. Mereka memandang orang hitam Afrika diidentikan dengan keras dan kuat, oleh karena itu pantas dijadikan pekerja keras. Hak bicara, hak mengungkapkan perasaan dan meminta perlakuan manusiawai tidak berlaku. Tentu saja hal ini merupakan kenangan kelam bagaimana sebuah rasisme begitu kejamnya hingga mengancurkan nilai-nilai kemanusiaan. Hak asasi manusia pada saat itu benar-benar tidak dianggap melekat kepada semua orang sejak lahir, melainkan hanya melekat pada merekamereka yang memiliki hak istimewa Karen aterlahir dalam ras yang baik.

Saat ini banyak sekali warga Papua yang tinggal di luar Papua, entah untuk kepentingan pekerjaan, usaha ataupun pendidikan. Perlakuan-perlakuan yang mereka terima selama mereka berada di luar wilayah begitu menjadi perhatian. Tindakan-tindakan kecil yang dilakuan individu saat berhubungan dengan orang Papua yang dapat menyebabkan tindakan intoleran hingga rasialisme. Seperti kejadian yang di alami mahasiswa Papua yang merantau ke Jakarta untuk kuliah. Mereka terkadang kesulitan mencari kos-kosan karena tidak ada yang menerima orang Papua (tirto.id). Kemudian perlakuan lain yang kurang baik adalah mengatakan bahwa orang Papua memiliki aroma badan yang kurang enak sehingga mereka seringkali melihat mahasiswa di kampus sering menutup hidungnya saat mahasiswa asal Papua lewat.

Dikutip dari artikel Indoprogress.com mengenai Papua, pada tanggal 26 Oktober 2016, di Sanggeng, Manokwari, Papua Barat, terjadi kontak senjata yang mengakibatkan seorang lakilaki Papua tewas terkena peluru. Kasus lainnya adalah hak berbicara dan berpendapat dalam bentuk dialog dengan Jakarta terkait masalah Papua tidak diberikan ruang. Dialog tersebut justru dianggap sebagai suatu gerkan pemberontakan yang harus diselesaikan dnegan peluru oleh aparat terhadap orang Papua.

Beberapa peristiwa di atas sebenarnya tidak asing untuk kita ketahui. Tidak usah jauh-jauh, kita sendiri sebagai warga non Papua yang memiliki ciri-ciri fisik yang berbeda dengan orang Papua, setidaknya jika sudah melihat orang Papua berada di sekitar kita, kita akan mencuricuri pandang ke arahnya. Kita selalu melihat mereka seakan-akan mereka benar-benar berbeda dengan kita dalam konotasi yang negatif. Hal ini hampir mirip dengan peristiwa perbudakan di Amerika yang memandang warga kulit hitam lebih rendah derajatnya dibanding kulit putih. Warga kulit hitam seringkali mendapat yang berbeda dari kulit putih. Hal tersebut tentu saja sudah tidak sejalan dengan penghormatan terhadap hak asasi manusia. Bukan tidak mungkin, mereka sebagai orang Papua pasti merasa risih dengan tindakan yang demikian.

Sikap atau tindakan-tindakan merendahkan di atas dapat masuk dalam kategori etnosentrisme. Sikap merasa diri sendiri lebih baik dari mereka, dalam hal ini yakni ciri-ciri fisik. Tak jarang di acara-acara televisi nasional pun, sering 
terdengar nada-nada sumbang yang menyinggung ciri-ciri fisik orang Papua, yang tentunya merasa (ciri fisik) dirinya lebih baik dari Papua. Bermula dari hal-hal seperti ini, menjadi mungkin ketika meletus suatu masalah kecil antara orang Papua dan non-Papua, pasti kemudian meletus menjadi masalah besar. Inilah cikal bakal intoleran yang sering kita tida sadari.

Tindakan intoleransi biasanya dalam bentuk larangan atau tekanan terhadap bentuk-bentuk material, seperti makanan dan cara berpakaian. Juga dalam bentuk larangan mengenai kebiasaan, agama atau budaya yang berlanjut hingga menjadi diskriminasi dan intoleransi. Pada tahap yang lebih parah adalah tindakan kekerasan seperti menggusur, menyerang, dan menyiksa (voaindonesia.com). Hal ini yang terjadi pada peristiwa rasisme yang dilakukan aparat setempat terhadap mahasiswa Papua di Surabaya. Entah penyebab utamanya seperti apa, akan tetapi sikap dari aparat dan warga sekitar sangat menunjukkan sikap yang merasa derajatnya lebih tinggi dari mereka sehingga dapat bertindak sewenang-wenang. Tindakan tersebut berupa keluarnya ucapan-ucapan yang kurang berkenan bagi mahasiswa Papua. Bahaya rasisme adalah tindakan rasis yang melanggengkan distribusi kekuasaan yang tidak merata berdasarkan karateristik ras (Paradies, 2006).

Belum lagi jika sudah berbicara pada ranah agama dan keyakinan. Indonesia sebagai negara yang mayoritas warga negaranya beragama Islam, akhir-akhir ini sangat sensitif dengan halhal yang behubungan dengan non-islam. Warga Papua mayoritas beragama non-islam. Pluralisme diperlukan dalam hal ini. Tokoh pluralisme yang paling dikenal di Indonesia yakni Gusdur menyatakan bahwa pluralisme tidak seharusnya menjadi sumber konflik, melainkan seharusnya menjadi sarana bagi manusia untuk memahami anugerah Tuhan agar tercipta toleransi dan harmoni di tengah kehidupan (Kompas, 2010).

Toleransi dipahami sebagai kesediaan untuk bertahan dengan orang lain meskipun berbeda (Rapp, 2015). Seseorang dapat dikatakan toleran jika dia yang awalnya menolak suatu kelompok, kemudian memberikan mereka hak politik dan sosial yang sama terlepas dari kenyataan bahwa ia tidak menyukai kelompok tersebut. Menurut Undang-Undang Nomor 40 Tahun 2008 tentang Diskriminasi Ras dan Etnis, diskriminasi adalah tindakan pembedaan, pengecualian, pembatasan, atau pemilihan berdasarkan pada ras dan etnis yang mengakibatkan pencabutan atau pengurangan pengakuan hak asasi manusia. Peter Ballint (2015), memberikan dua strategi alternatif bagi sikap intoleran yaitu: (1) mencoba untuk mengubah rasa keberatan menjadi keyakinan atau sikap yang jauh lebih positif dengan asumsi bahwa perilaku kurang baik lama-lama akan berkurang, dan (2) mencoba mengubah rasa keberatan menjadi ketidakpedulian terhadap karakteristik rasial tertentu.

Sikap atau tindakan intoleran ini seringkali berimplikasi hal yang sama. Seperti contoh pada kasus pelarangan pendirian masjid di Papua. Seperti dilansir dari tirto.id mengenai Di Balik Polemik Penolakan Menara Masjid di Papua yang diunggah pada tanggal 20 Maret 2018. Tindakan warga nasrani Papua yang menolak adanya renovasi masjid Agung Al-Aqsha di Sentani, Papua merupakan dampak dari sikap yang sama ketika sejumlah warga muslim di luar papua menghambat kebebasan beribadah penganut kristen.

Sebuah jurnal psikologi menyebutkan bahwa mahasiswa Papua di Surabaya mengalami berbagai hambatan dalam menyesuaikan diri dengan lingkungannya saat merantau. Perbedaan fisik dan warna kulit sebagai penyebab hambatan tersebut. Hambatan ini menimbulkan dampak persona dan sosial. Mereka kemudian cenderung memilih bergaul hanya dengan sesama mahasiswa Papua. Hal tersebut menimbulkan lingkungan pergaulan mereka sangat terbatas. Meskipun mereka sedang merantau, mereka seperti tidak bisa memanfaatkan lingkungan baru mereka untuk bisa berbaur dengan warga setempat dan mempelajari budaya lain di luar Papua.

Warga Papua sesungguhnya dapat hidup dengan sangat toleran. Mereka melakukan akulturasi budaya sebagai sebuah keharusan penyesuaian dalam masyarakat. Warga lokal dan warga pendatang di Papua melakukan perubahan dan mengikutinya. Hal tersebut tidaklah merugikan dan para warga dapat hidup berdampingan dan menjalankan budayanya (Anakota: 2019).

Hasil penelitian mengenai kajian skala karakter toleransi (Supriyanto \& Wahyudi: 2017), menemukan tiga aspek yaitu kedamaian, menghargai perbedaan dan individu, serta kesadaran. Salah satu aspek di atas yang relevan dengan pembahasan ini adalah mengenai aspek menghargai perbedaan dan individu yakni meliputi indikator saling menghargai satu sama lain.

\section{Siklus Rasisme terhadap Orang Papua}

Pada tahun 2016, di Yogyakarta, salah seorang mahasiswa Papua ditangkap paksa, asrama mereka dikepung organisasi masyarakat dan mahasiswanya dikriminalisasi. Peristiwa ini terjadi saat mahasiswa Papua akan menyuarakan aspirasinya di jalan dalam rangka menyuarakan isu ras Melanesia. Akan tetapi aksi tersebut dhentikan oleh aparat keamanan dan 
ormas. Polisi menangkap salah satu mahasiswa Papua bernama Obby Kogoya. la diperlakukan tidak manusiawi oleh polisi. Tubuhnya dibanting, lehernya diapit siku, dan lubang hidungnya dmasuki dua jari polisi kemudian ditarik. la mengaduh kesakitan. Peritiwa tersebut berhasil diabadikan oleh seorang jurnalis yang kemudian tersebar luas di sosial media. Akan tetapi pihak kepolisian menyatakan bahwa tidak ada kerusuhan apapun dan juga menyangkal mengenai foto yang sudah tersebar, mereka mengatakan itu adalah hoaks.

Pada tahun 2017, terjadi pembubaran aksi demontarsi dan diskusi-diskusi yang sedang diadakan oleh mahasiswa Papua. Aksi demonstrasi peringatan hari kedaulatan Papua di Jakarta dilarang oleh polisi. Berkat hasil negosiasi, demonstrasi itu akhirnya dapat tetap berjalan dengan dijaga oleh 400 personel polisi dan tiga mobil rumah tahanan.

Kemudian beberapa diskusi yang pernah dibubarkan antara lain, diskusi aliansi mahasiswa Papua dibubarkan oleh kelompok ormas di Malang. Ada pula diskusi pemutaran film 'Peringatan 20 Tahun Peristiwa Biak Berdarah' di Surabaya dibubarkan aparat gabungan TNI, Polri dan Satpol PP dengan alasan operasi yustisi.

Adapun kisah rasisme lain yang dialami mahasiswa Papua yang kuliah di tanah Jawa adalah yang terjadi pada beberapa mahasiswa Papua di Jakarta. Para mahasiswa tersebut tidak menduga bahwa dirinya akan mengalami masamasa sulit. Mereka mengalami kesulitan mencari kamar kos. Pernah menghampiri sebuah koskosan, tetapi pemilik kos bilang bahwa kosannya sudah penuh dan ia tidak bisa menerima orang Papua.

Selain itu, sikap rasisme lain yang dialami mahasiswa Papua di Jakarta adalah saat mereka berbelanja di toko. Pemilik toko terebut enggan melayani mereka dengan baik. Pada saat itu mereka meminta pemilik toko untuk mengantar dan memasangkan gas di kos-kosan mereka, namun pemilik toko terebut menolak dengan mengatakan bahwa mahasiswa Papua bau. Bahkan kasus rasisme juga dialami saat di kampus. Ada seorang dosen yang pernah menanyakan langsung apakah mereka suka makan babi atau tidak. Dan tentu saja hal itu dijawab tegas oleh mahasiswa Papua bahwa merek atidka pernah memakan bagi secara mentah, melainkan dmasak dahulu.

Beberapa tindakan rasisme yang diterima orang Papua karena mereka dianggap tukang buat onar. Nyatanya stigma itu tidak selamanya benar. Iswahyudi, adalah warga asli Tangerang yang memiliki kenangan manis saat bertetangga dengan mahasiswa Papua. Iswahyudi menceritakan walaupun pada mulanya merasa asing dengan orang Papua, namun lambat laun warga dan mahasiswa tersebut dapat berbaur dengan baik. la mengatakan dulu dirinya sering diajak masuk ke kontrakan mahasiswa Papua untuk diajarkan mata pelajaran sekolah. la menyatakan bahwa framing Papua oleh orang-orang yang tidak bertanggung jawab itu salah besar. Orangorang Papua nayatanya asyik diajak bergaul dan dapat berteman baik. Satu hal yang penting adalah untuk menghargai perbedaan.

Cerita baik lain datang dari Bandung, warga yang bertetangga dengan tempat tinggal mahasiswa dari Papua menyatakan bahwa hubungan mereka dengan warga sekitar cenderung baik, meskipun dulu suka ada ributribut karena sering mabuk-mabukan, nyatanya sekarang mereka hidup berdampingan dengan baik dengan warga sekitar.

Rasisme erat kaitannya dengan sistem perbudakan yang meiliki sejarah panjang dalam peradaban manusia. Dua hal tersebut berhubungan erta karena paham dan tindakan rasis lahir dari perbudakan. Praktik perbudakan dan tindakan rasis tidak ada bedanya. Keduanya memiliki semangat superioritas yang sama (Mulait, 2019). Hal tersebut dilandasi karena bangsa atau pribadi tertentu merasa diri atau rasnya lebih tinggi daripada ras lain. Hal ini tentu senada dengan konsep etnosentrisme.

Ujaran rasis yang dialami orang Papua adalah suatu konsep yang diterjemahkan ke dalam tindakan diskriminatif. Dalam perjuangan orang Papua sebagai bangsa yang beradab, suah mengalami tindakan diksriminatif hampir di seluruh lini kehidupan dan yang paling keras adalah pelrindungan hukum dan keamanan (Mulait, 2019). Hukum d republik ini seakan tidka berlaku bagi orang Papua. Ketika orang Papua diperlakukan kurang manusiawi, harkat dan martabatnya dihina dengan tindakan kekerasan ataupun pembunuhan oleh oknum tertentu baik sipil maupun militer, tidak berlaku hukuman bagi pelakunya.

Kasus-kasus pelangagaran hak asasi manusia yang terjadi pad aorang Papua banyak yang tidak diproses secara hukum. Maka dari itu tidka heran banyak tindakan sewenang-wenang yang dlakukan orang-orang non Papua terhadap orang Papua.

Jaminan keamanan pun menjadi terancam bagi orang Papua dnegerinya sendiri. Dari beberapa kasus yang sudah dijelaskan di atas, sudah kentara sekali bahwa pemerintah melalui tangan aparat kemanan menggunakan cara-cara teror dan kekerasan terhadap orang Papua. Hal ini tentu dlakukan atas adasar superioritas. Seperti ujaran rasis yang terjadi pada mahasiswa Papua di Surabaya yang dilakukan oleh aparat. Tentu itu atas dasar etsontrisme itu.

Sebuah tulisan opini yang dtulis langsung oleh orang Papua dalam artikel mengenai Papua di SuaraPapua.com menyatakan bahwa rasime terhadap orang Papua seperti ideologi terselubung. la mengisahkan ada anak-anak kecil di Jawa secara spontan memanggil mahasiswa 
Papua yang lewat dengan sebutan monyet. Pengalaman lain juga dtemukan bahwa ketika orang-orang Papua naik angkot, seringkali masyarakat yang ada satu angkot dengan mereka menutup hidung atau buang muka.

Kasus lain yang senada terjadi saat kesebelasan sepak bola asal Papua (Persipura) yang hendak bermain diteriaki monyet dan dlempari kulit pisang. Dari beberapa peristiwa di atas menjadi suatu ujaran yang lazim secara terstrukutur dan masif. Peristiwa-peritiswa yang mungkin terkesan biasa bagi orang non Papua ini memperlihatkan semacam ideologi terselubung dalam pola pikir masyarakat Indonesia. Hal tersebut yang membuat kesan orang Papua sebagai orang yang cenderung dekat dengan hal-hal yang negatif dan dinomorduakan atau bahkan dianggap binatang.

Tindakan-tindakan rasisme tersebut tentu melukai hati semua orang Papua. Dan yang lebih menyayat hati lagia adalah fakta bahwa tindakan rasialis tersebut dbantah oleh aparat ketika peristiwa rasialis muncul di Surabaya. Pihak aparat justru mengklaim bahwa tindakan rasialis yang dilakukan oleh pihaknya merupakan pemanfaatan isu demi kepentibgan politik kelompok-kelompok yang ada hubungannya dengan orang Papua (Mulait, 2019).

\section{KESIMPULAN}

B erdasarkan tulisan di atas dapat ditarik kesimpulan bahwa sikap etnosentrisme dan sikap intoleran merupakan tindakan yang dapat memecah belah bangsa. Tindakan tersebut sangat tidak dibenarkan oleh undangundang. Toleransi merupakan identitas sikap permisif masyarakat terhadap pendapat, kepercayaan, dan praktik yang berbeda dari milik sendiri (Preston, 2018).

Mengingat Indonesia adalah negara besar dengan penduduknya yang majemuk, sudah menjadi barang tentu menumbuhkan sikap toleransi adalah suatu kewajiban bagi penduduknya. Sikap toleransi ini agar terciptanya hubungan warga negara yang baik satu sama lain. Sebenarnya bukan hanya ada tataran di dalam negeri saja kita harus memiliki sikap toleran, melainkan dalam hal apapun dan dimanapun saat kita menemukan sebuah perbedaan.

Menguatnya sentimen keetnisan terkait dengan sebuah situasi ketidakadilan di berbagai bidang termasuk ekonomi dan politik, sosial dan budaya yang dihadapi oleh sebuah kelompok etnis, baik berupa pengabaian, eksploitasi, dominasi, represi atau diskriminasi (Rozi: 2009). Papua adalah provinsi yang kaya akan sumber daya alam bagi Indonesia, akan tetapi kerap kali diperlakukan dengan semena-mena oleh warga non Papua. Dari beberapa kasus rasisme yng terjadi warga Papua berbuntut ada peristiwa bentrok yang dilakukan warga Papua terhadap pemerintah setempat sebagai tindakan protesnya. Jika hal ini dibiarkan berlarut-larut, maka bangsa Indonesia tidak pernah belajar untuk dapat mengamalkan semboyan Bhineka Tunggal Ika yang sesungguhnya.

Peristiwa-peristiwa kericuhan yang terjadi di Papua dan Papua Barat yang merupakan buntut dari tindakan rasisme yang terjadi pada mahasiswa Papua di Surabaya. Aksi tersebut merupakan akumulasi dan kegerahan yang drasakan masyarakat Papua atas tindakantindakan rasis yang selama ini mereka alami. Gerakan separatis yang ada di Papua yakni Operasi Papua Merdeka (OPM) bisa menjadi ancaman serius jika masalah rasisme yang dilakukan masyarakat Indonesia non Papua terhadap orang Papua terus berkelanjutan dan tidak pernah ada titik terangnya. Apa perlu bagi mereka, orang Papua, meminta intervensi asing agar pemerintah Indonesia dapat memberikan sikap tegas atas tindakan-tindakan rasisme yang dialami orang Papua.

Namun demikian, ada beberapa kisah yang tidak selamanya menggambarkan hubungan kurang baik antara masyarakat Indonesia non Papua dengan orang Papua. Masih ada merekamereka yang memiliki pemikiran yang maju yang masih mengedepankan hati nurani dan menghormati hak asasi manusia, menghormati persamaan dearajat sebagai sesame manusia cipataan Tuhan yang memperlakukan orang Papua dengan baik. Hal-hal yang demikian sebenarnya yang dapat memperbaiki hubungan antara masyarakat non Papua dengan orang Papua agar terciptanya hubungan yang harmonis sebagai sesama orang Indonesia.

Menjadi catatan penting bahwa Indonesia negara majemuk, dan bersikap toleran sudah menjadi kewajiban bagi bangsa Indonesia terhadap seluruh ras dan etnis yang ada di Indonesia. sikap-sikap toleran tersbeut bisa dilakukan dengan cara mencoba untuk mengubah rasa keberatan menjadi keyakinan atau sikap yang jauh lebih positif dengan asumsi bahwa perilaku kurang baik lama-lama akan berkurang. Sikap lain yang bisa dilakukan adalah dengan cara mencoba mengubah rasa keberatan menjadi ketidakpedulian terhadap karakteristik rasial tertentu dengan sikap yang tetap menghormati satu sama lain. 


\section{E. UCAPAN TERIMAKASIH}

T erimakasih penulis sampaikan kepada Samsuri selaku dosen pembimbing yang telah membimbing dan mengarahkan penulis dalam menyusun artikel ini. Terimakasih juga penulis sampaikan kepada Program Pascasarjana Universitas Negeri Yogyakarta yang telah memberi dukungan untuk penerbitan artikel.

\section{DAFTAR PUSTAKA}

Ahmadi, A. (2007). Psikologi sosial edisi revisi (Cetakan Ketiga). Jakarta:PT. Rineka Cipta.

Anakota, R. (2019). Akulturasi Masyarakat Lokal dan Pendatang di Papua Barat. Jurnal Antropologi: Isu-isu Sosial Budaya, Vol. 21 No.1 (35).

BBC.com. Mahasiswa Papua bicara soal rasialisme: 'ih kalian bau' dan tudingan tukang minum. Artikel dterbitkan 23 Agustus 2019 dan diakses pada 18 Mei 2020. https://www.bbc.com

Balint, P. (2016). The Importance of racial tolerance for anti-racism. Ethnic and racial studies, VOL. 39, NO. 1, 16-32, http://dx.doi.org/10.1080/01419870.2016.1099713

Deda, J.A. \& Mofu, S.S. (2014). Masyarakat Hukum Adat dan Hak Ulayat di Provinsi Papua Barat sebagai Orang asli papua ditinjau dari sisi adat dan budaya: sebuah kajian etnogafi kekinian. Jurnal Administrasi Publik, Vol. 11 Nomor 2 ISSN 1412-2740.

Faqieh, M. (2010). Fatwa dan Canda Gus Dur. Jakarta: Kompas.

Irianto, A. M. (2013). Integrasi Nasional sebagai Penangkal Etnosentrisme Di Indonesia. Humanika vol.18 No.2 DOI: https://doi.org/10.14710/humanika.18.2.

Indoprogress.com. HAM, Gereja Katolik dan Orang Asli Papua. Artikel ini diterbitkan pada 10 November 2016 dan diakses pada tanggal 16 April 2020. Indoprogress.com/2016/11/HAMgereja-katolik-dan-orang-asli-papua/

Indoprogress.com. Papua, Stigma, \& 1965. Artikel diterbitkan pada 22 September 2016 dan diakses pada tanggal 16 April 2020. Indoprogress.com/2016/09/papua-stigma-dan-1965/

Mahmud. (2011). Metode Penelitian Pendidikan. Bandung: Pustaka Setia.

Myers, D. G. (2012). Psikologi sosial, edisi 10 buku 1. Jakarta: Salemba Humanika.

Paradies, Y. (2006). Defining, Conceptualizing and Characterizing Racism in Health Research. Critical Public Health, VOL.16 (2): 143-157.

Preston, J. (2018). You are embued with tolerance. Artchitecture and Culture journal, DOI $10.1080 / 20507828.2018 .1551050$

Purbasari, V. A. (2019). Interaksi Sosial Etnis Cina-Jawa Kota Surakarta. Jurnal Antropologi:Isu-isu Sosial Budaya, Vol.21 No. 01.

Rapp, C. (2015). More diversity, less tolerancy? The effect of type of cultural diversity on the erosion of tolerance in swiss municipalities. Ethinc and Racial studies, Vol. 38, No. 10, 1779-1797, http://dx.doi.org/10.1080/01419870.2015.1015582

Rozi, S. (2009). Nasionalisme, Demorkatisasi, dan Sentimen Primordialisme di Indonesia: Problematika Identitas Keetnisan versus Keindonesiaan pada studi kasus Aceh, Papua, Bali, dan Riau. Jurnal LIPI Vol. 6 No.1 DOI: https://doi.org/10.14203/jpp.v6i1.529

SuaraPapua.com. Menyusuri historis rasis terhadap orang asli Papua. Artikel dterbitkan pada tanggal 8 oktober 2019 dan diakses pada tanggal 21 Mei 2020. https://suara-papua.com

Supriyanto, A. \& Wahyudi, A. (2017). Skala Karakter Toleransi: Konsep dan Operasional Aspek Kedamaian, Menghargai Perbedaan dan kesadaran Individu. Jurnal IImiah Counsellia, Vol. 7 No. $2(61-70)$.

Susanto, E. H. (2009). Etnosentrisme, Pemekaran Wilayah dan Komunikasi Antar Budaya. Jurnal Untar. http://repository.untar.ac.id/id/eprint/487

Tempo.co. Setara Institue : Intoleransi terhadap Keyakinan Meningkat. Artikel diterbitkan pada 20 Agustus 2018 dan diakses pada tanggal 26 September 2019. https://nasional.tempo.co/read/1118802/setara-institut-intoleransi-terhadap-keyakinanmeningkat/full\&view=ok

Tirto.id. Di Balik Polemik Penolakan Menara Masjid Di Papua. Artikel diterbitkan pada 20 Maret 2018 diakses pada tanggal 25 September 2019. https://tirto.id/di-balik-polemik-penolakan-menaramasjid-di-papua-cGrd

Voaindonesia.com. Jaringan Gusdurian: Praktik Intoleransi dalam Masyarakat Menguat. Artikel diterbitkan pada 19 Desember 2018 diakses pada tanggal 26 September 2019. https://www.voaindonesia.com/a/jaringan-gusdurian-praktik-intoleransi-dalam-masyarakatmenguat/4704193.html 
Wijanarko, E., \& Syapiq, M. (2013). Studi Fenomenologi Pengalaman Penyesuaian Diri Mahasiswa Papua di Surabaya. Jurnal Psikologi: Teori \& Terapan, vol.3 No.2 (83-84).

Wikipedia. Papua. https://id.wikipedia.org/wiki/Papua diakses pada tanggal 27 September 2019. 